\title{
Marketing Communication Strategies for Generation Y - Millennials
}

\author{
Ljupka Naumovska \\ University of Tourism and Management Skopje, Macedonia, the republic of the former \\ Yugoslavia \\ E-mail: ljupka.naumovska@gmail.com
}

Received: April 7, 2017 Accepted: April 14, 2017 Published: June 4, 2017

doi:10.5296/bms.v8i1.10260ＵRL: https://doi.org/10.5296/bms.v8i1.10260

\begin{abstract}
The marketing academics and researchers have studied members of Generation Y, recognized as Millennials who are born between the late ' 70 s and middle ' 90 s. This particular interest for research of Millennials continues due to questions concerning buying habits, consumer psychology and other related specifics, shaping this group as noticeably different in various means from its predecessors.

Generation $\mathrm{Y}$ is a distinctive and dominant consumer group whose behavior, habits and consumers' psychology is often discussed but not fully comprehended yet. Severely influenced by the technology revolution, the digital media development and the Internet, this market segment has developed differently from previous generations making it an interesting group for targeting for advertisers and brands. At this point, Generation $\mathrm{Y}$ is the largest market segment; hence the increased interest in categorizing and understanding characteristics of Generation Y from marketers. A contribution to the marketing theory and industry can be made with this paper, providing useful data for the consumer behavior of Generation Y, deeper understanding for their buying habits and consumer's profile and most importantly media preferences as a basis for deeper and qualitative consideration of this marketing segment.
\end{abstract}

Keywords: marketing, communications, consumers, millennials 


\section{Introduction}

\subsection{The Importance of Millennials as Market Segment}

Millennials are distinctive demographic and psychographic market segment whose consumer behavior and habits is often discussed in the literature but not fully comprehended (Noble et al., 2009; Smith, 2012). Severely influenced by technology, the digital media development and the Internet, this market segment has developed differently from previous generations making it an interesting group for targeting by marketers and brands with marketing campaigns and sales promotions (Lester et al., 2005).

At this point, Generation $\mathrm{Y}$ is the largest market segment and far bigger than their previous generation. Member of Generation $\mathrm{Y}$ have specific and unique physiognomies and as a customers are very distinctive when it comes to purchase decisions and brand preferences. Generation Y has developed in over-advertised, brand- conscious world and consequently, they are savvy when it comes to brands and products selection (Moriarty, 2004).

Members of Generation Y have contrasting social ambitions: au thought their main concern is self-gratification, as a parallel trend they are thriving for social improvement (Boyd, 2010). Beside the fact that some markeres have described this market as a homogenous group, Millennials are quite diverse segment, composed of groups that demand complex marketing concepts and thorough media mix (Geraci, 2004).

The main hypothetical frame is related with indicators and research question centered around 2 main hypotheses: the media preferences and content preferences of Millennials for communication campaigns.

\subsection{The Importance of Multigenerational Marketing Concept}

Individuals belonging to one of the existing age groups have similar interests, observations, standards and lifestyles that influence their consumer behavior and define their characteristics as consumers. The understanding of unique characteristics of different age groups ensures solid base for marketers aiming to create more effective marketing and brand communications strategies and designing communication messages. (Howell, 2012)

The Baby Boomers were born between 1946-1964, between the end of World War II and 1964. (Williams and Page, 2010). In terms of social behavior they value individualization, self-expression and optimism. (Walker, 2003) Boomers largely identify themselves with their professional vocations and many are recognizing themselves as workaholics. (Koco, 2006) Beside professional achievements, also, family bonds are important to Boomers. (Dietz, 2003) Health, vitality, and wellness are major goals for them. They are considered more self-centered and doubtful of authority (Binder, 2010). Baby Boomers are good customers for traveling services, leisure, fitness trainers, motorcycles, and financial consulting services.

Generation X was born during 1965-1980 and reached adulthood during difficult economic times; hence, professional rise for this generation has been much more challenging. They are 
likely to be self-employed professionals who embrace freelancing over company loyalty (Cranston, 2008). In terms of social life, they grew up rapidly, facing increasing divorce rates and domestic violence, but still they value family first. They are highly educated, but pessimistic, skeptical, even sarcastic for most of things (Moore and Carpenter, 2008). Generally, they are free agents, not team players (Cranston, 2008). Generation X as customers is much insecure and hesitative. Marketers should mind their low level of loyalty toward brands and companies (Williams and Page, 2010). They are fond of products such as automobiles, home appliances, and children's products.

Generation Y was born between years 1980 - 2000. They are children of the Baby Boomers and grew up in a time of constant economic and global change such as rise of woman leaders, inclusion movements for ethnic and cultural diversity including an ecological and social awareness, technological, electronic, and digital expansion, and global economic processes.. In terms of marketing communication, marketers face real challenge when trying to capture the attention of the audience - members of Generation Y (Talay, 2015). They are unlikely to respond positively to marketing stimuli in comparison with Baby Boomers and Xers. In terms of visuals, marketers need to use more visuals, graphics, animations and videos. In terms of wording and copy writing, creative designers must use a story-telling language and wordings that challenge actions. They respond well on humor and are reluctant on ,too serious,, advertising messages. They show very small interest on television media (Williams and Page, 2010), and are more related to social media, interactive platforms and fond of fast communication: instant messaging, texting and social media platforms: Facebook and Twitter. Content is most important for Generation Y (Spencer, 2009).

Generation $\mathrm{Z}$ is the youngest generation, composed of individuals born after year 2001. They have witnessed economic recession, global crisis and parallel negative trends that lead to their loss of childhood (Bashford, 2010). However, Generation Z individuals are self-controlled, aware and accountable. They are comfortable to high-tech and multimedia devices, and never lived without the Internet. They are ready to be on mission, and are fond of fantasy. They are least loyal to employers and brands. The basic three key characteristics of Generation $\mathrm{Z}$ are: instant gratification, gamified succes, and open-minded social values (Williams and Page, 2010). Fashionable wardrobe, music, fashion, cosmetics, and on line games are very important products for Generation $\mathrm{Z}$. The youngest members of this generation - Children are able to identify brands from the age of about 18 months; whish arouses attention concerning moral and ethical issues when creating advertising messages (Calvet, 2008). According to Calvet, children younger than eight are especially vulnerable to mass media marketing messages because they lack the intellectual skills to understand the persuasive intent of the advertiser. Marketers should be aware that Generation $\mathrm{Z}$ is easy dealing and manipulating with technological devices and hence intensively exposed to digital and social media.

\subsection{The Unique Characteristics of Generation $Y$}

In socio-psychological perspective Millennials are ethnically diverse more than any preceding generation. They value expressiveness and creative activities, art and science. 
Beside the heavy consequences of the global economic downturn such as high unemployment, low income and big loans, due to high education levels and optimism, they have professional and creative ambitions. One of the positive aspects they raised thriving to establish themselves is investing in startups and following the own entrepreneurial interests.

\subsection{Brand Preferences of Generation $Y$}

In terms of brand and product preferences, Millennials are attracted to authentic, handmade, locally produced goods - and they're willing to pay more for products from companies with active socially responsible programs. In terms of interactions, technology greatly defines Millennials consumer behavior. Namely, modern consumers belonging to Generation Y are demanding personal connections with brands that appeal to their emotions, principles, standards, and feelings. Also they look for products, services and brands that relate to their lifestyle and help to promote their ideal self (Howell, 2012). These two aspect are perfectly comprehended with digital devices, social media and tech product.

\section{GROWING WILLINGNESS TO SPEND MORE ON PRODUCTS FROM SOCIALLY RESPONSIBLE COMPANIES}

\section{CHANGE FROM 2011 TO 2013}

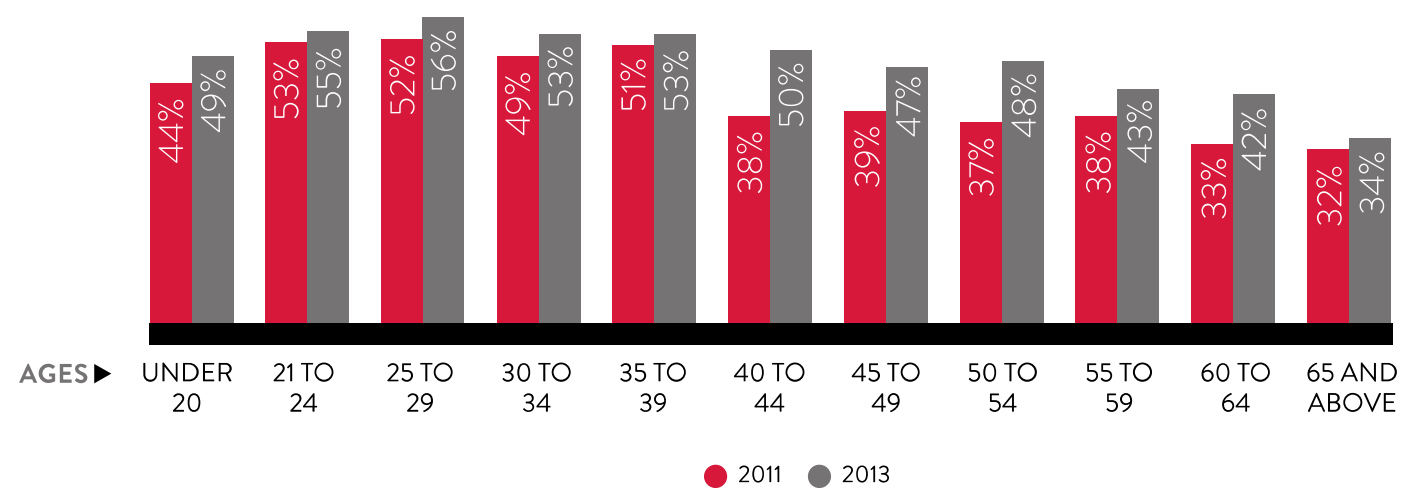

Figure 1. Preferences of Generation Y for socially responsible related products

Source: Nielsen Global Survey on Corporate Social Responsibility 2013.

This type of preference toward socially ,,good,, brand and products is widely accepted by marketing experts and thus implemented in the overall marketing strategy in the past 5-7 years by global brands. Examining the characteristics and traits of the Millennial generation is useful for marketers, as it suggests new marketing strategies to reach this large and affluent segment.

\subsection{Media Channels Preferred by Generation $Y$}

Planning a media mix for targeting consumers of Generation $\mathrm{Y}$ is challenging in many aspects. Namely, Millenials frequently use diverse media especially digital media (Hershatter and Epstein, 2010). 


\section{Macrothink}

Millennials are mostly attached to wearable technology devices, which makes mobile phones and lap tops an efficient way to locate, follow or target them.

Generation $\mathrm{Y}$ individuals watch a smaller amount of television, and are unlikely to be influenced by conventional media. At the same time they are unaffected to advertisements and show ignorance messages more than previous generations (Ciminillo, 2005; Engebretson, 2004; Pesquera, 2005).

Millennial app usage in terms of both unique audience and time spent, is led by Facebook Mobile and then followed by other social media apps like Instagram and Twitter. Millennials also spend time playing games on their smartphones in spare time more then any other previous generation.

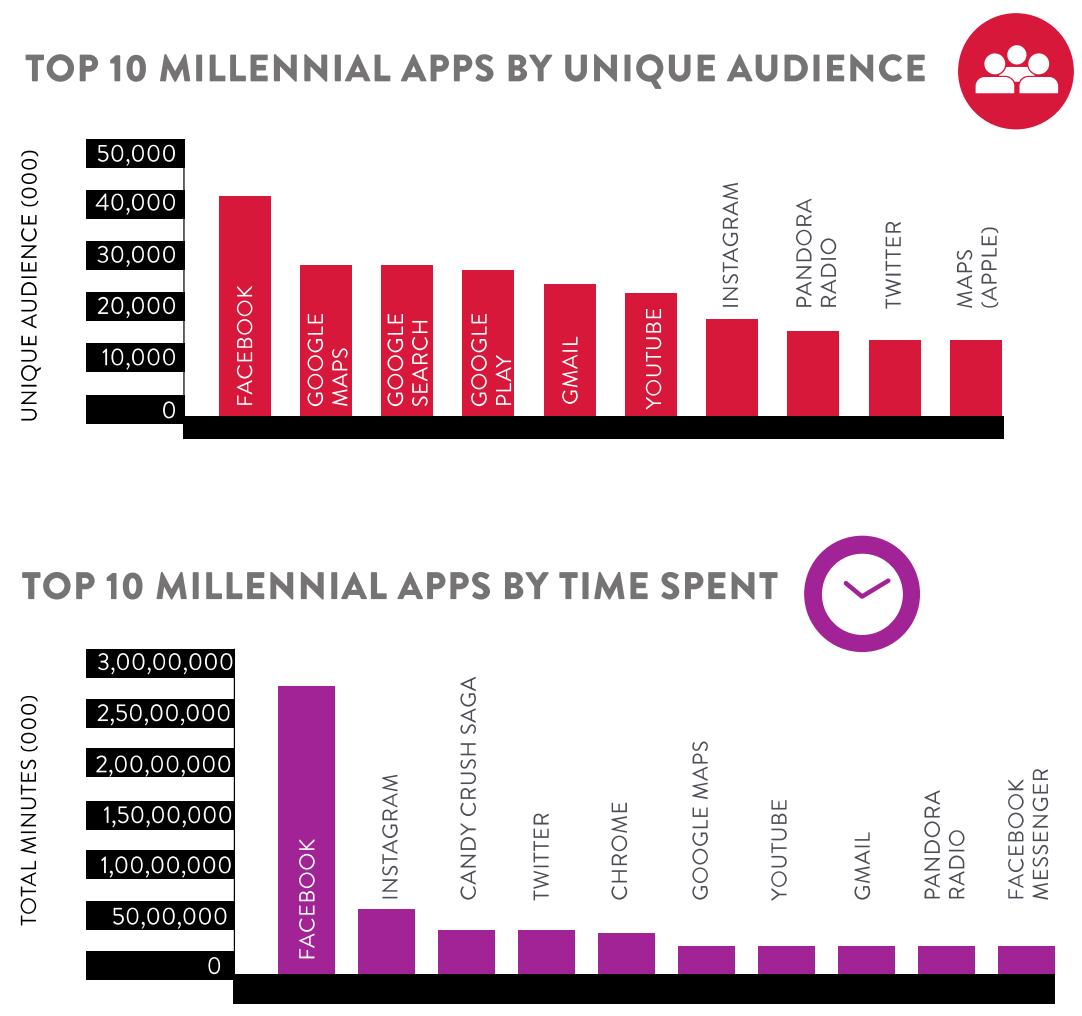

Figure 2. Top apps used by Millennials

Source: Nielsen Global Survey on Mobile Net view 2013.

Most of the Millennials have grown with the Internet and are skillful at using it for product and price comparison and buying. The Internet is their primary and most credible source of information. Therefore, most of the global brand have easily adopt their sales strategy applying e-business and e-commerce techniques so they can directly target this segment.

Many retailers use these web sites to connect and interact with Generation Y consumers using the methods for games, engaging and feedback (Engel et al., 2011). 
Individuals of Generation $\mathrm{Y}$ were raised in an over-advertised, brand-conscious world, therefore they respond to advertising messages differently that previous generation do, preferring to be informed about products and services through sources other than traditional media. For this reason, many companies are relying less on traditional media advertising and more on event marketing, promotions and digital media (Ciminillo, 2005). In terms of creative content for advertising, for a message to appeal to a potential customer of Generation Y, it must be rapid, direct, and truthful (Pesquera, 2005). Regarding the Public Relations, the audience of generation $\mathrm{Y}$ does not trust the traditional news media as much as previous generations (Peterson, 2004). As for the sales promotions, this generation dislikes being a promotional campaign target, so they rely more on their friends' recommendation and word-of-mouth when making buying choices (Peterson, 2004). In developing creative content, marketers use humor as a concept widely accepted by Millennials.

\section{Hypothesis}

Based on the preceding review of the literature the following hypotheses were formulated. Millennials are predominantly using the digital media for social interactions, work- related tasks, and purchasing goods. Believing that Millennials spend most of their time on line, hypotheses 1 is formulated.

H1. Millennials prefer getting information about the brand on digital media

Speaking in psychographic manner, Millenials like to feel special and prefer personal and emotional appealing when receiving message. Therefore brands must offer consumers a personalized relationship. Since Millennials have the desire to feel special, hypotheses 2 was formulated accordingly.

H2. Personalized digital messaging and marketing is the most successful at attracting the attention of Millennials.

Analyzing the preferable creative concept for marketing campaigns, for a message to appeal to a customers belonging to Generation Y, it must be honest, emotional and fun. Hence, Hypothesis 3 is formulated:

H3: The marketing messages with honest and realistic concepts and story are mostly preferable for Millenials.

\section{Method}

For the purpose of this paper, survey was conducted of 172 Millennials from Macedonia, Bulgaria and Greece were surveyed in summer 2016. The respondents were between the ages of 25 and 34. Males accounted for $44 \%$ of the respondents, while females accounted for $56 \%$.

The survey was distributed via e-mail of 330 individuals out of which 172 responded.

The method of research is quantitative and presented with histograms in the result section. The questions from the survey are related with indicators with the main hypothesis, and 
centered around given variables.

\section{Results and Discussion}

For the purpose of this paper, 172 Millennials from Macedonia, Bulgaria and Greece were surveyed in summer 2016. The respondents were between the ages of 25 and 34. Males accounted for $44 \%$ of the respondents, while females accounted for $56 \%$.

H1. Millennials prefer getting information about the brand on digital media rather than traditional.

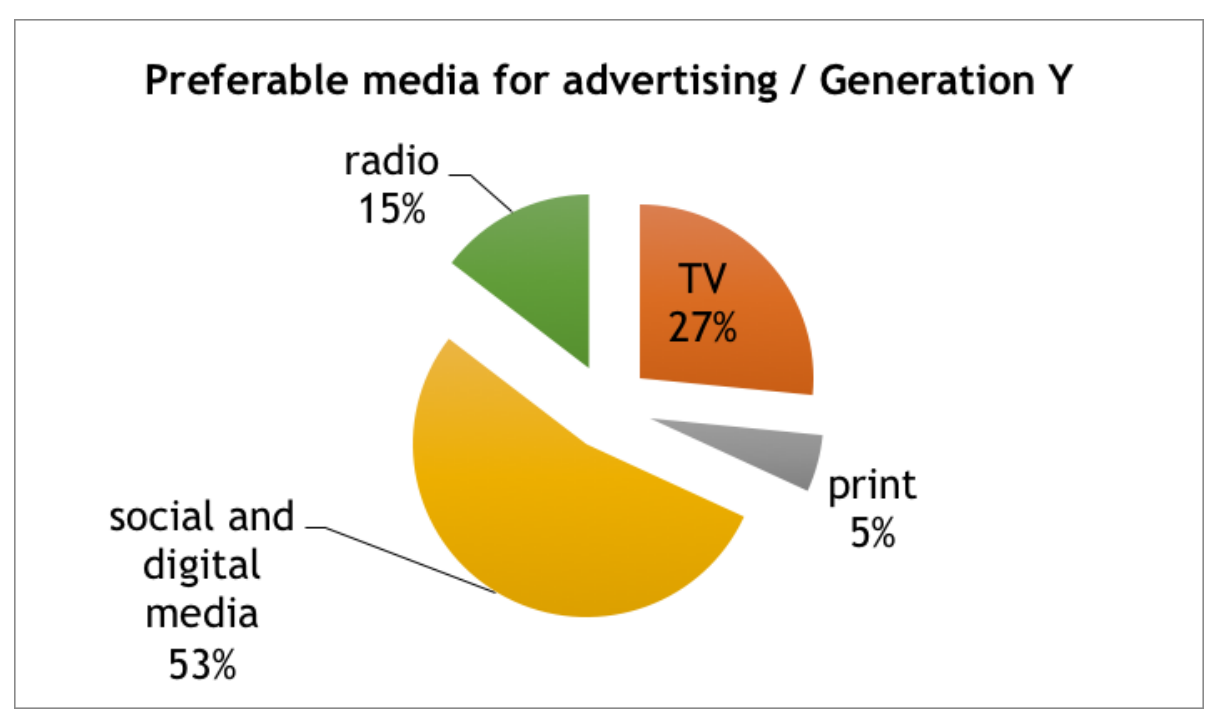

Figure 3. H1 / Q1: What media do you prefer when exposed to advertising?

Common forms of media were analyzed, TV, radio, print, social platforms and web portals. Respondents were allowed to select 2-3 types of advertising that they most prefer. Results strongly supported hypothesis 1; Millennials do use web portals and social platforms. Over $53 \%$ of respondents chose these two channels as their preferred means for advertising and messaging. Still some of them (27\%) also support TV media as relevant for brand campaigns and advertising.

H2. Personalized messaging and marketing is the most successful at attracting the attention of Millennials.

Respondents were asked to look at advertising posters and select up to 2 creative solutions that were most likely to grab their attention. 


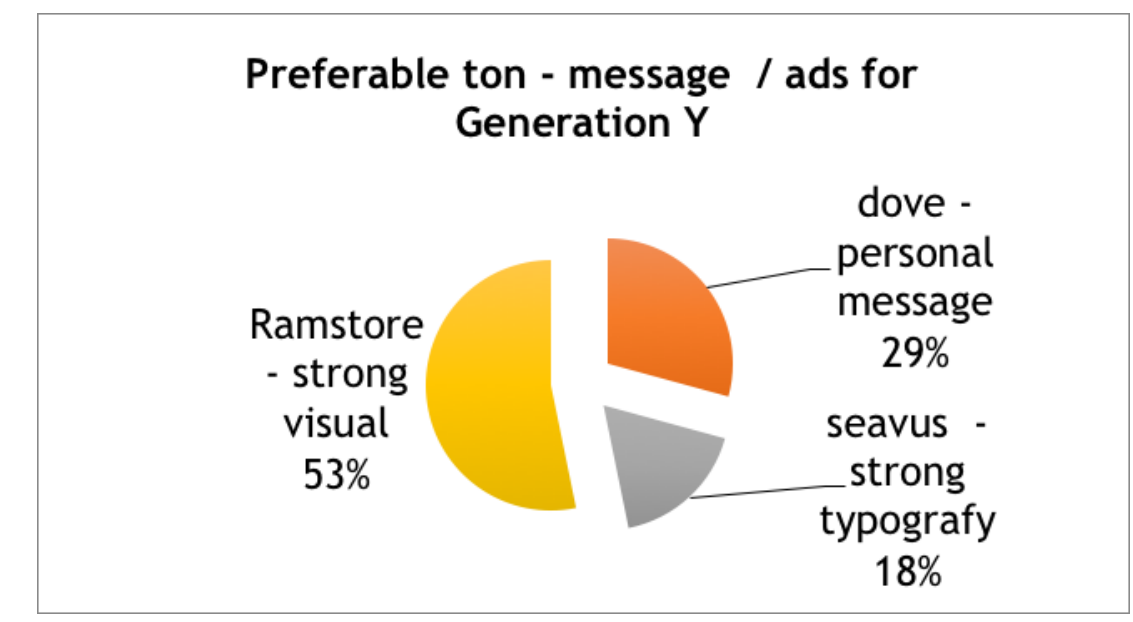

Figure 4. H2 / What tone of advertising message is the most successful at attracting the attention of Millennials

While $29 \%$ of the respondents said that personalization on a message grabs their attention, personalization was not the most effective strategy in this endeavor. Thus, hypothesis 3 was not fully supported. The marketing strategy that overwhelmingly grabs the attention of a Millennial is the one that use graphics and strong visuals.

H3: The honest marketing messages are mostly preferable for Millenials.

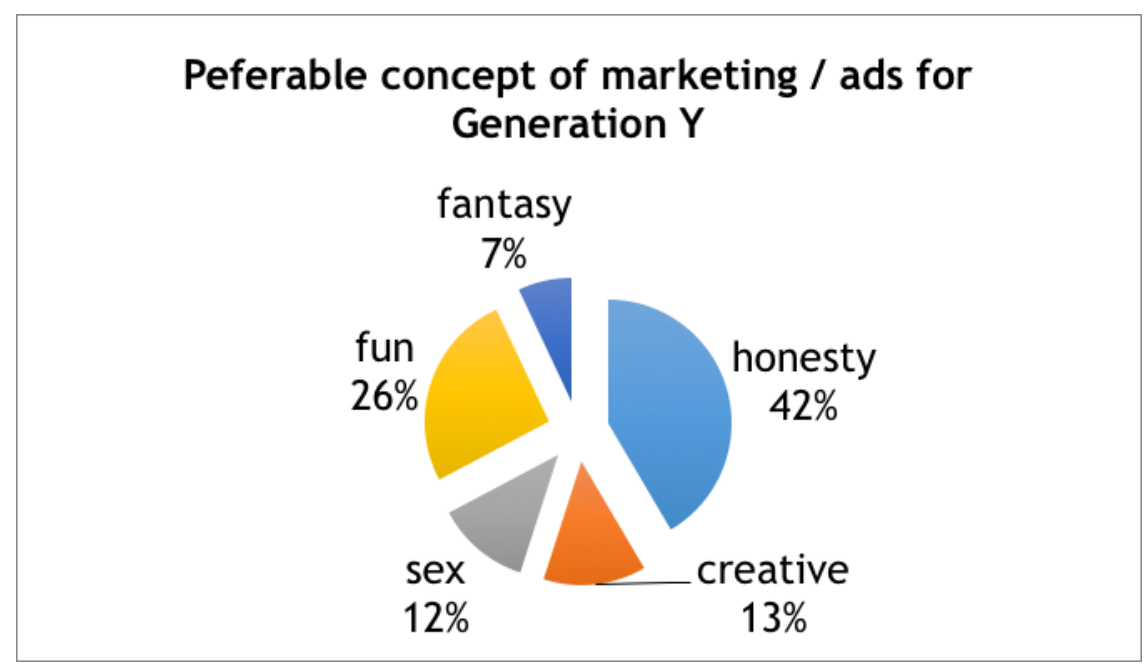

Figure 5. H3 / What concept for advertising do you prefer?

One way to increase product awareness, build a reputation, or gain customers is to have Millennials as brand ambassadors, loyal customers building brand community organically. Experts suggest that honest appealing in wording is essential for this. The research strong supports this hypothesis with $89 \%$ of the respondents choosing honesty as a drive concept in packaging, design, PR and slogans.

\section{Conclusion}

Marketers are rethinking their strategies for targeting the largest consumer group - 
Millennials. The brands that were popular with their parents are being rejected by this generation. Having grown up in an even more media-saturated, brand-conscious world than their parents, they respond to ads differently. The shift in brand preference may be due to a shift in values, lifestyle and preferences on the part of Millennials. They want lives that are less structured and value more time for them. They have the view that there is more to life than work. This generation is very connected to their friends and acquaintances.

There is general agreement that digital media greatly impacted the way a marketer reaches Millennial customer. Also, the personal and honest marketing concept has created new trends in creative business widely accepted and shared by Generation Y.

The connectedness they obey via internet, digital platforms and social media makes them available any time so they can communicate at any time, from anywhere, and in various forms.

There is a growing tendency for consumers to put more trust in the opinions of other consumers rather than company generated information. This can be underlined by the trend that Internet, social networking, and inter-active technologies are empowering Millennials to be more active in the creation and advancement of products and brands. Word-of-mouth goes around the world these days via Internet. This generation wants to have input regarding all aspects of a product, even its promotion. Successful marketers should realign their techniques in order to positively engage these vocal consumers.

In creativity manner, advertisers should use positive, emotionally meaningful concepts, words, and images, e.g., tell them a story they will connect with. They are environmentally conscious and supportive of the awareness campaign for social movement and green products and services.

For a business, one of the most valuable benefits of using digital media is its capacity to offer consumers a personalized relationship with strong graphics and visual communication elements.

Hence, the successful model for integrated marketing communication for targeting Generation $\mathrm{Y}$ is based on media mix with predominant digital media and social platforms. Creative message that is personal and emotional, if possible containing elements of fun and humor including clear visuals and graphic. The course of the communication will remain interactive and personal in future. Having said that, the brands and advertisers carried by marketing preferences of the Millennials who are about to be the biggest capital holders and decision makers have a challenge to address differently and more profoundly containing greater cause and advocacy than just selling the product.

\section{References}

Bashford, A. (2010). Internationalism, Cosmopolitanism, and Eugenics. In Alison Bashford and Philippa Levine (Eds.), The Oxford Handbook of the History of Eugenics, (pp. 154-172). New York: Oxford University Press. 
Berk, M., Talay, Janell, Townsend, D., \& Sengun, Y. (2015). Global Brand Architecture Position and Market-Based Performance: The Moderating Role of Culture. Journal of interactive marketing. (June, 2015). http://dx.doi.org/10.1509/jim.13.0164

Binder, L. J. (2010). Bridging the Generation Gap. Marketing Health Services, Spring, 22-24.

Boyd, D. (2010). Social Network Sites as Networked Publics: Affordances, Dynamics, and Implications. In Networked Self: Identity, Community, and Culture on Social Network Sites(ed. Zizi Papacharissi), pp. 39-58. [pdf]

Calvert, L. S. (2008). Children as consumers: advertising and marketing. Available at http://www.researchgate.net/publication/49852129, retrieved May 2015

Cranston, B. (2008). Talkin' 'bout Their Generations. $\quad B+T$ Weekly, May 2, 10-11.

Dietz, J. (2003). Defining Markets, Defining Moments: America's 7 Generational Cohorts, Their Shared Experiences, and Why Businesses Should Care. The Journal of Consumer Marketing, 20(2/3), 172-174. http://dx.doi.org/10.1108/07363760310464622

Drake-Bridges, E., \& Burgess, B. (2010).nPersonal preferences of tween shoppers. Journal of Fashion Marketing and Management, 14(4), 624-633. http://dx.doi.org/10.12691/jbms-3-3-3

Engebretson, J. (2004). Odd gen out. American Demographics, 24(4), 14-18.

Hershatter, A., \& Epstein, M. (2010). Millenials and the world of work: an organization and management perspective. Journal of Business Psychology, 25(2), 211-223.

Howell, R. (2012). Market Segmentation: the Importance of Age Cohorts. Retrieved from http://www.neumann.edu/academics/divisions/business/journal/Review2012/Howel 1.pdf, 21.

Lester, D. H., Forman, A. M., \& Loyd, D. (2005). Internet shopping behavior of college $\begin{array}{llll}\text { students. } & \text { Services } \quad \text { Marketing, } & \text { Quarterly, 27(2), }\end{array}$ http://dx.doi.org/10.1108/JCM-07-2013-0650

Moore, M., \& Jason, M. C. (2008). Intergenerational Perceptions of Market Cues among US Apparel Consumers. Journal of Fashion Marketing and Management, 12(3), 323- 337. http://dx.doi.org/10.1108/13612020810889281

Moriarty, R. (2004). Marketers target savvy ' $Y$ ' spenders: hip imagery, sophisticated sales pitches, web sites are designed to appeal to youth. The Post Standard, 8 February, p. 2004.

Neuborne, E. (1999). Generation Y today's teens - the biggest bulge since the boomers - may force marketers to toss their old tricks", Business Week, 15 February.

Noble, S. M., Haytko, D. L., \& Phillips, J. (2009). What drives college-age Generation Y consumers? Journal of Business Research, 62(6), 617-628. http://dx.doi.org/10.1108/JCM-07-2013-0650

Pesquera, A. (2005). Reaching Generation Y. San Antonio Express-Newsz, 29, 1. 
Peterson, K. (2004). Savvy Gen Y isn’t buying traditional sales pitches. The Seattle Times, May, p. 17.

Racolta-Paina, N. D., \& Luca, T. A. (2010). Several considerations regarding the online consumer in the 21 st century - a theoretical approach. Management \& Marketing, 5(2), 85-100.

Smith, K. T. (2012). Longitudinal study of digital marketing strategies targeting Millennials. The Journal of Consumer Marketing, 29(2), 86-92.

Spencer, M. (2009). Millennial Generation Influenced by 9/11, Tech, and Now Obama. McClatchy - Tribune Business News, January 18.

Srinivasan, S., Rolph, A., \& Kishore, P. (2002). Customer Loyalty in E-Commerce: An Exploration of its Antecedents and Consequences. Journal of Retailing, 78(1), 41-50.

Walker, E. (2003). The Value of Generational Marketing. National Underwriter, 107(29), 24.

\section{Copyrights}

Copyright for this article is retained by the author(s), with first publication rights granted to the journal.

This is an open-access article distributed under the terms and conditions of the Creative Commons Attribution license (http://creativecommons.org/licenses/by/4.0/) 